\title{
Management of contact dermatitis due to nickel allergy: an update
}

\author{
Fernanda Torres' \\ Maria das Graças \\ Mota Melo 2 \\ Antonella Tosti ${ }^{3}$ \\ 'Department of Dermatology, Federal \\ University of Rio de Janeiro, Rio \\ de Janeiro, Brazil; ${ }^{2}$ Occupational \\ Dermatology Sector, Center for the \\ Study of Worker Health and Human \\ Ecology, National School of Public \\ Health, FIOCRUZ, Rio de Janeiro, \\ Brazil; ${ }^{3}$ Department of Dermatology, \\ University of Bologna, Bologna, Italy
}

Correspondence: Antonella Tosti Department of Dermatology, University of Bologna,Via Massarenti, I-40I38, Bologna, Italy

Tel +3905 I 6364840

Fax +39 05I 347847

Email antonella.tosti@unibo.it

\begin{abstract}
Nickel is the major cause of allergic contact dermatitis in the general population, both among children and adults, as well as in large occupational groups. This metal is used in numerous industrial and consumer products, including stainless steel, magnets, metal plating, coinage, and special alloys, and is therefore almost impossible to completely avoid in daily life. Nickel contact dermatitis can represent an important morbidity, particularly in patients with chronic hand eczema, which can lead to inability to work, a decrease in quality of life and significant healthcare expenses. Therefore, its management is of great importance. This article reviews diagnostic, preventive and therapeutic strategies in this field.
\end{abstract}

Keywords: allergic contact dermatitis, metals, contact hypersensitivity, occupational exposure, children, contact dermatitis

\section{Introduction}

"Nickel is with you and does things for you from the time you get up in the morning until you go to sleep at night." This phrase from the brochure "The Romance of Nickel" clearly shows that this metal is present in a large variety of products, and therefore is almost impossible to avoid. ${ }^{1,2}$

Nickel is an important cause of allergic contact dermatitis (ACD) in the general population, both among children and adults, with a worldwide prevalence of around $8.6 \% .^{3}$ The prevalence among young females is even higher, around $17 \%{ }^{4}$

Most cases are due to nonoccupational exposure. Nickel allergy affects women 3 to 10 times more than men and is usually due to daily contact with jewelry, garments and wristwatches. ${ }^{5-7}$ Some experimental studies suggest that women are more likely to develop contact sensitivity than men. ${ }^{8}$

As an occupational disease it particularly affects men, but the number of women with occupational exposure is increasing. ${ }^{9}$ Nickel allergy can cause inability to work and require change of jobs. Workers particularly exposed to nickel include cashiers, hairdressers, jewelers, dental technicians, auto-mechanics, electroplaters, dyers, homemakers and persons who manipulate nickel-plating hand tools. ${ }^{10}$

A genetic predisposition possibly plays a role and a study has shown that women who become sensitized to nickel have an higher prevalence of HLA-B35 and BW22 antigens. ${ }^{11}$ The importance of genetic factors has also been studied in children. ${ }^{12-14}$ Loss-of-function mutations in the filaggrin gene are likely to increase the risk of nickel allergy. ${ }^{15}$

Nickel is the number one allergen in frequency of positive patch test reactions. Reports from the North American Contact Dermatitis Group (NACDG) revealed that $16.2 \%$ of the US population showed a positive reaction to nickel, documenting an increase from $14.3 \%$ in the 1994-1996 study period. ${ }^{16}$ In Central Europe, $12.9 \%$ of the patch tested population is positive to this metal. ${ }^{7}$ In another study of the European Surveillance System of Contact Allergies 20\% of 9871 tested patients were sensitized 
to nickel, with the highest prevalence in Italy $(32.2 \%)$, and lowest in Denmark (9.7\%). ${ }^{17}$ Duarte showed that in adolescents with a positive patch test reaction, $31 \%$ were allergic to nickel, making it the most common allergen in this age group. ${ }^{18}$

Nickel contact dermatitis represents an important morbidity that can lead to inability to work, a decrease quality of life and significant healthcare expenses. Therefore its management is of great importance. This article reviews diagnostic, preventive and therapeutic strategies in this field.

\section{Source of sensitization}

Sensitization to nickel can occur from skin contact with jewelry and consumer products, from occupational exposure and experimentally. It can occur either by exogenous (skin contact) or endogenous exposure (oral, inhalation).

\section{Jewelry and consumer products}

Ear piercing is the most common cause of sensitization, and thus represents a strong risk factor for nickel allergy, even in men. ${ }^{3,6,19,20}$ About $81.5 \%$ of nickel positive patch-tested women have pierced ears. ${ }^{3}$

Nickel ACD occurs when metallic items, corroded by human sweat, saliva, and other body fluids, release free nickel ions that act as haptens, inducing sensitization. ${ }^{21,22}$ This explains why nickel allergy depends on climatic factors, as sweating increases the release of nickel from nickel-plated items. ${ }^{23}$

Nickel exposure amount per skin unit area can be quantifed as $\mu \mathrm{g} / \mathrm{cm}^{2}$ and may vary over time depending on skin contact. It is then more relevant to look for "low nickel release" than for "nickel free" items.

In 1990, Denmark legislated a limit of $0.5 \mu \mathrm{g} / \mathrm{cm}^{2} /$ week of nickel release from nickel-containing alloys and coatings. ${ }^{24}$ In 1994, the European Union adopted a similar legislation. ${ }^{25}$ Due to this directives, a decline in the prevalence of nickel allergy was observed in Denmark and Germany. ${ }^{26,27}$ However despite of these new regulations, the metal is still the most common allergen detected by patch testing all over Europe. ${ }^{7,18}$

Stainless steel and white gold usually release less than $0.5 \mu \mathrm{g} / \mathrm{cm}^{2} /$ week but nickel-coated items typically release more than that, and thus represent an important cause of elicitation or aggravation of ACD in previously sensitized individuals. ${ }^{28}$ In addition there is evidence that a proportion of nickel-allergic individuals can react even in the presence of lower levels of exposure. Rasenen demonstrated that stainless steel ear-piercing kits that release less than $0.05 \mu \mathrm{g} / \mathrm{cm}^{2} /$ week could induce sensitization. ${ }^{29}$
Among consumer products, nickel can be found in make-up, washing liquids and powers, and other household products, but these only exceptionally cause allergy in nickel-sensitized individuals. ${ }^{30,31}$

Several cases of nickel ACD in neonates and infants have been described and sources of sensitization in this age group are numerous, including earrings, jewelry worn by the mother, bed rails, metal buttons and snaps in underwear, identification bracelets, safety pins, zippers, jeans and belt buckles, metal accessories, shoes, coins, metal toys, magnets, medallions, keys, and door handles. ${ }^{32-37}$

Nickel ACD can also occasionally be induced by orthodontic appliances, which can cause cheilitis, perioral eczema, stomatitis and even systemic dermatitis on the eyelids, fingers, ears, and periorbital area. ${ }^{38-39}$ However, nickel sensitization is lower in adolescents who wear dental braces before ear piercing as they may develop immunological tolerance. ${ }^{6,40}$

It is controversial whether or not metal plates utilized in orthopedic surgery could sensitize or exacerbate a preexisting nickel allergy and even lead to rejection of the hip replacement. ${ }^{22,41}$ However there is general agreement that nickel allergy is not a contraindication for the application of a stainless steel or vitallium metal hip.

\section{Occupational exposure}

Nickel is an important occupational allergen, even though the prevalence of occupational dermatitis from nickel is not known. A Brazilian study showed occupational exposure in $39 \%$ of 404 patients with positive patch test to metals. ${ }^{42}$ A recent study of the North American Contact Dermatitis revealed that $13.1 \%$ of 5,148 patch-tested patients had occupational-related skin dermatitis. ${ }^{43}$

Industrial exposure, particularly in the plating industry is significant. It may not only cause contact dermatitis, but also asthma, nasal septum perforation, pneumonia, and nasal and lung cancer. ${ }^{44}$

Industrial uses of nickel include production of stainless steel, nickel alloys and nickel cast iron, electroplating and electroforming, manufacture of alkaline batteries (nickel cadmium batteries), catalysts, coin manufacture, production of welding products including nickel electrodes and filler wire, production of sintered components, pigments, and electronics.

Usually primary sensitization occurs from nonoccupational sources and work exposure aggravates the dermatitis, but occasionally primary sensitization occurs in the workplace, mainly from wet works with nickel contact. 
Workers develop chronic hand eczema, as many work tools release large amounts of the metal which can also penetrate through rubber gloves. ${ }^{45}$ Generally $30 \%$ to $40 \%$ of patients with occupational nickel allergy develop hand eczema. ${ }^{46}$ Involvement of the hands in a nickel-sensitized patient should raise the possibility that nickel is acting as an occupational allergen. ${ }^{9}$

\section{Experimental sensitization}

Experimental sensitization to nickel has been largely studied. Vandenberg showed that $9 \%$ of individuals repeatedly exposed to $25 \%$ nickel chloride in $0.1 \%$ sodium lauryl sulfate solution were sensitized. ${ }^{47}$ Kligman was able to induce nickel allergy in 12 of 25 patients exposed to $10 \%$ nickel sulfate solution by irritating the skin. ${ }^{48}$

\section{Multiple sensitizations to metals}

Nickel allergy is frequently associated with reactivity to other metals, mainly chromium and cobalt, but whether this is a result of cross-reactivity or multiple sensitizations is still under debate.

Since metallic items often contain multiple metals, as in stainless steel (iron/nickel/chromium), copper-nickel and nickel-silver (nickel/copper/zinc) multiple sensitization can easily occur. Besides, cross-reactivity requires chemical similarities that are not present in such cases.

Cross-challenge experiments carried out in guinea pigs to clarify simultaneous patch-test reactivity and possible crossreactivity to metals (nickel sulfate-cobalt chloride; nickel sulfate-potassium dichromate, nickel sulfate-palladium chloride), show that cross-reactivity is possibly involved in reactions to nickel sulfate-palladium chloride but not in reactions to nickel sulfate-cobalt chloride and nickel sulfatepotassium dichromate. ${ }^{49-51}$

It has also been suggested that sensitization to one allergen facilitates sensitization to another unrelated chemical. Lammintausta performed a study in guinea pigs sensitized to nickel and found that they could be more easily sensitized to cobalt. ${ }^{52}$ In another study, the same author compared patch test reactions in nickel-positive and nickel-negative female patients and found that cobalt allergy was significantly more common in nickel-positive patients. ${ }^{53}$ Duarte patch tested 1208 patients with a presumptive diagnosis of contact dermatitis, and found that $404(33.5 \%)$ had at least one positive reaction to nickel and/or cobalt and/or chromium, with 487 positive reactions to metals ( $48 \%$ of all positive reactions). Approximately $18.5 \%$ had positive reactions to two or three metals and the association of nickel and cobalt was the most frequently observed. ${ }^{42}$

\section{Methods}

A review of the literature was carried out using PubMed-Medline and contact dermatitis and occupational skin disease books. Key search terms included: nickel contact dermatitis, nickel contact allergy, nickel sensitization, nickel, children contact dermatitis, and metal contact dermatitis. In addition, references of relevant articles and reviews were manually searched for additional sources. Bibliographies of retrieved publications were reviewed to identify sources not obtained in our search.

A summary of the evidence and proposed recommendations were then generated.

\section{Approach to patients with nickel ACD}

Management of nickel contact dermatitis include early diagnosis and preventive and therapeutic strategies.

\section{Diagnosis}

\section{History and clinical examination}

A detailed history should investigate possible source of exposure, including daily activities, environmental conditions, past and current occupations and manipulation of products. In children, it is important to examine and question their parents and careers.

Clinical features include localized primary eruptions or generalized secondary eruptions, which can be eczematous or not.

Primary eruptions are characterized by recurrent eczematous lesions on the sites of direct contact with the items that release nickel, such as earlobes (use of earrings), wrists (use of watches), neck (use of necklaces) and umbilical region (jeans button). ${ }^{54}$ The face and scalp may be involved from contact with cellular phones, piercing, and hair clasps., ${ }^{3,55-57}$

In sensitized individuals, transcutaneous, inhalatory, intravenous or oral exposure to nickel can cause a systemic allergic contact dermatitis. Clinical features include involvement of previous exposed areas (flare-up of dermatitis and/or patch test sites), as well as unexposed areas (maculopapular exanthema, pompholyx, flexural eczema, "baboon syndrome", and vasculitis-like lesions) and general symptoms (headache, malaise, fever, arthralgia, pirosis, nausea, diarrhea and vomiting).

The maculopapular exanthema with flexural involvement presents as a symmetrical eruption of the neck, face, eyelids, elbow flexures and forearms, hands, inner thighs, anogenital regions, and may be generalized. ${ }^{58}$ 
Pompholyx has been associated with nickel allergy in women, adolescents and twins, but this issue still remains controversial. ${ }^{59-61}$

The "baboon syndrome" is a rare, characteristic, dark-violet to pink eruption in the area of the buttocks, genital area and inner thighs. The name denotes a characteristic clinical picture reminiscent of the red gluteal region of a baboon. The flexural predilection of the eruption is unclear, and it could be only partially explained by local occlusion and sweating. ${ }^{58,62}$

Systemic allergic contact dermatitis to nickel is haptenspecific and with a clear dose-response relationship. Immunological investigations in nickel-sensitive individuals whose dermatitis flared after oral nickel provocation showed that CD8+ "memory" CLA+ T lymphocytes and T lymphocytes with a type 2-cytokine profile are involved. ${ }^{63}$

Rarely nickel causes noneczematous dermatitis, such as contact urticaria, papular lichenoid eruption and vasculitis-like lesions. ${ }^{64,65-67}$

\section{Patch testing}

Contact allergy is diagnosed by patch testing. As this test measures only whether the individual is sensitized or not, a positive test reaction is not necessarily an indicator of clinical disease. Clinical relevance of patch test results should always be established. There is a high degree of concordance between history of nickel exposure and outcome of patching testing. ${ }^{68,69}$

Nickel is the most common positive patch test allergen. It has been estimated that nickel-positive tests are seen in $10 \%$ to $30 \%$ of female patients, $2 \%$ to $8 \%$ of male patients, $15.9 \%$ of children and $13.7 \%$ of patients older than 65 , but it varies greatly, depending on the selected population. ${ }^{7,70,71}$ Although sensitivity and sensibility of patch testing is not exactly known, reproducibility is generally high, even though results may vary in the same patient at different times. $^{72-74}$

The standard patch test concentration of nickel sulfate is $5 \%$ pet in Europe and $2.5 \%$ pet in the USA. Positive reactions are usually strong.

False-positive reactions may occur in atopics, where follicular irritative reactions are common. Weak true-positive reactions can also show a follicular pattern.

False-negative reactions can also occur. In case of strong clinical suspicion, the test can be repeated with nickel chloride $5 \%$, which increases nickel concentration, by using penetration enhancers such as dimethyl sulfoxide (DMSO) or scratching the skin before patch test application.
Since patch tests are often performed by different specialists including allergologists, dermatologists, pediatricians, and general physicians, special training is essential to correctly judge and interpret the test in order to distinguish allergic from irritative reactions and establish patch test relevance.

Patch testing is considered safe in children, but positive reactions should be assessed with caution. Some limitations include the small patch test surface, hyper mobility (which may result in loss of patch test materials), particularly in younger children, and the hesitation of some parents to allow patch testing. Some authors recommend the same patch test concentration as in adults, but others recommend lower allergen concentration. ${ }^{75}$ In case of doubtful reactions it is advisable to retest with a lower concentration.

\section{Dimethylgloxime (DMG) spot-test}

This test identifies metallic objects that contain high nickel concentrations (at least 1:10,000) and can be useful to screen personal items in individuals allergic to nickel. An object that gives a negative result is unlikely to induce the dermatitis. Dermatology staff may test a patient's metal alloys in the office or nickel-sensitive patients can purchase a test kit and be taught how to use it at home to screen jewelry, metallic surfaces or any other metal object.

The spot-test kit contains 1\% dimethilgloxime in alcohol solution $(30 \mathrm{~mL})$ and $10 \%$ ammonium hydroxide solution $(30 \mathrm{~mL})$. There are two methods to perform the test. Fisher's original method consists in putting a few drops of each solution on the metallic object; a positive reaction is denounced by a pink-red precipitate. ${ }^{76}$ Most metal alloys give a positive reaction, except stainless steel.

A modification of this technique was proposed by Shore who suggests applying a few drops of DMG and then a few drops of ammonium hydroxide on a cotton-tipped applicator that is then rubbed against the object. A pink-red precipitate on the applicator tip detects a positive reaction. ${ }^{77}$

The test can roughly quantify the nickel content as the precipitate color can vary between pale pink to red.

\section{Experimental oral provocation}

This technique is not routinely recommended, but it is a possibility in patients with pompholyx when a possible role of nickel is suspected.

Nickel dietary intake varies from $0.1 \mathrm{mg}$ to $0.5 \mathrm{mg}$, and thus the induction of systemic dermatitis by foods remains controversial, as experimental doses are usually higher than those introduced with foods. ${ }^{78-81}$ 
Several studies had been performed in order to induce flare-ups of nickel dermatitis by oral challenge, particularly in patients with pompholyx. ${ }^{82-88}$ It was shown that flare-up occurs in a dose-response way. ${ }^{78,89}$

\section{Finger immersion test}

The patient is asked to put one or more fingers in a solution containing nickel to see which concentrations in consumer products can cause a flare-up of hand eczema. ${ }^{90}$ It might be indicated in selected cases of hand eczema, particularly in an occupational subset.

\section{The lymphocyte proliferation test}

This test can be useful in the diagnosis of nickel sensitivity. Duarte showed that lymphocyte proliferation was higher in patients allergic to nickel (17 patients) than in controls (25 patients) for all the nickel concentrations tested. ${ }^{91}$

\section{Prick test}

This may be indicated in cases of contact urticaria due to nickel.

\section{Intradermic test}

Intradermic test is almost never used on clinical practice, but it may be utilized in case of doubtful patch test reactions, either to identify false-positive reactions or to confirm a clinical suspicion of nickel dermatitis in patients with negative patch tests..$^{92}$ It can also reveal the degree of sensitivity with different titrations, which can't be done with standard patch tests. ${ }^{93}$

\section{Preventive strategies Avoidance of nickel}

The only way to prevent recurrence is avoiding skin contact with metallic items that release nickel. It has been documented that this strategy results in a statistically significant decrease in the frequency of hand eczema in nickel-sensitive individuals. $^{94}$

Although metallic items that could not be avoided are often covered with enamel, dye or adhesive this procedure may carry the risk of inducing sensitization to these compounds.

In a recent study, Sprigle evaluated the ability of four different barrier coatings in obtaining a negative DMG test and showed that Nickel Guard ${ }^{\circledR}$ (proprietary ingredients) and Beauty Secrets Hardener ${ }^{\circledR}$ (a clear nail polish not containing tosylamide/formaldheide resin) were most effective, the latter being the more cost-effective choice. ${ }^{95}$
Patients should be instructed to buy stainless steel or gold earrings and change the metallic buttons with buttons made by plastic or brass.

Cosmetics often contain nickel and some products such as mascara and eye shadows might cause or aggravate ACD, particularly in patients with eyelid involvement. ${ }^{96-98}$ "Nickel-free" cosmetics available in the market contain less than 1ppm of nickel and can be safely used by most sensitized patients.

\section{Antiperspirants}

The use of antiperspirants in order to decrease sweating can sometimes prevent nickel ACD, as sweating induces release of nickel ions from metallic items.

\section{Smoking}

Heavy smoking is a risk factor for nickel allergy, as the metal is found in tobacco with an average content of 1 to $3 \mu$ g per cigarette. ${ }^{3,99}$

\section{Therapeutic strategies}

Therapy of nickel contact dermatitis can be very challenging and depends on clinical manifestations.

\section{Symptomatic treatments}

Since pruritus is an important complaint sedating oral antihistamines might be indicated. Topical antihistamines on the other hand must be discouraged, as they are possible sensitizers. Oral doxepin (10-25 $\mathrm{mg}$ at night in adults) can be considered if other oral antihistamines are not helpful. ${ }^{100}$

Acute exudative or bullous lesions can be treated with cool antiseptics compresses, three times a day, and topical steroids. Topical or oral antibiotics must be prescribed in case of secondary bacterial infection. Emollients in creams are useful to relief itching and dry skin.

\section{Steroids}

Topical steroids are very useful and represent the first-line treatment. Potency should be chosen according to the body sites, as low potency steroids are recommended for face and flexural areas and high potency agents might be used for other sites as palms and soles.

Oral steroids act as immunosuppressive agents and might be indicated for short-term treatment of severe dermatitis. In adults prednisone in a single morning dose of 40 to $60 \mathrm{mg}$ can be prescribed and tapered over 2 to 3 weeks, as symptoms resolve. 


\section{Calcineurin inhibitors}

Calcineurin inhibitors are currently approved for the treatment of atopic dermatitis but not ACD. Advantages over topical corticosteroids include that they do not cause cutaneous atrophy or glaucoma or cataracts when applied near the eye. Pimecrolimus cream might be used for the face and tacrolimus $0.1 \%$ ointment can be used for ACD of the hands. ${ }^{101,102}$

\section{Psoralen plus UV-A}

Some patients with chronic ACD can benefit for PUVA. Kalimo treated with PUVA 5 female patients with longstanding hand dermatitis with complete resolution after 1 year. However sensitivity of blood lymphocytes to nickel after treatment was approximately the same or increased which provides no evidence to indicate that systemic, nickelspecific suppressive immune regulative mechanisms would have been activated by the treatment. ${ }^{103}$

\section{Disulfiram}

It has been shown that disulfiram can chelate nickel, interfere with its absorption and metabolism and then improve nickel contact dermatitis, particularly pompholyx. ${ }^{85}$ this agent can be considered only in nickel-sensitized patients with severe hand involvement refractory to all other treatments as it can cause severe side effects including liver toxicity. It is also important to inform the patients that they cannot drink alcohol during treatment. Adult dose is $500 \mathrm{mg} \mathrm{PO}$ qd and 125 to $500 \mathrm{mg}$ PO qd for maintenance. ${ }^{100}$

\section{Binding agents and barrier creams}

It is known that some topical and oral substances can chemically bind nickel and prevent nickel ACD. ${ }^{104}$ These substances promote chelation of nickel, and thus prevent its antigenic properties; they are usually used in combination with others treatments, such as topical steroids. ${ }^{105}$ Barrier creams act as an "invisible glove", protecting the skin from environmental allergens. ${ }^{106}$

The most utilized binding agent is ethylene diamine tetra-acetic acid (ETDA), which can be included at a 15\% concentration in a cream in association with topical steroids. Memon showed that a cream containing 15\% ETDA and 1\% hydrocortisone was able to reduce the allergic reactions to patch tests with 20 pence coins ( $16 \% \mathrm{NI}, 84 \% \mathrm{Cu}$ ) in 10 of 26 nickel-sensitive subjects challenged for 2 days. ${ }^{107}$

Wöhrl demonstrated the preventive effect of $10 \%$ diethylenetriaminepentaacetic acid in an oil-in-water emulsion in nickel-sensitized patients. ${ }^{108}$
Another binding agent is 5-chloro-7-iodoquinolin-8-ol (clioquinol), which was able of prevent allergic reaction in 2 days, in a cream containing clioquinol $3 \%$ and hydrocortisone $1 \%{ }^{109}$ Clioquinol is commercially available in association with hydrocortisone or flumethasone.

Preparations containing diphenythiocarbazone, diphenylglyoxime and tartaric acid have been investigated for their ability to detoxify $\mathrm{NI}^{2}+$ in vitro. The preparation with diphenylglyomime was shown to have a positive effect. Kolpakov demonstrated that a cream containing $1 \%$ dimethylglyoxime (DMG) delayed but did not prevent the penetration of $\mathrm{NI}^{2}+$ (as $10 \%$ or $20 \%$ solutions of $\mathrm{NiSO}_{4}$ and/or $\mathrm{NiCl}_{2}$ into damaged skin in vitro). ${ }^{110}$

The efficacy of barrier creams in nickel allergy, particularly in patients with hand dermatitis, has been studied. ${ }^{111}$ Starek showed that an association of hydrocarbons, silicon and cetaceum have inhibiting effects on the absorption of nickel through the skin. ${ }^{12}$

Most commercially available barrier cream contains silicones and moisturizing agents.

\section{Low-nickel diet}

Food is important source of nickel and daily ingestion depends both on the type of food and on the production environment. Foods with high nickel content include wholegrain flour, oats, soybeans, legumes, shellfish, nuts, licorice and chocolate. ${ }^{113}$ The efficacy of prescribing a diet is still controversial as the daily oral uptake from food is much lower than the doses utilized to produce symptoms in experimental studies. However, it has been shown that some patients might benefit from a nickel free or a low nickel diet. ${ }^{114,115}$

Dietary restriction must be prescribed according to Veien's guidelines. ${ }^{116}$ Patients should be followed for 1 to 2 months to evaluate outcome before deciding if dietary restrictions should be maintained or not.

\section{Nickel hyposensitization}

Since nickel sensitization is a hapten-specific immunological process, it is possible to induce immune tolerance to this metal. As already discussed in this article, it had been shown that oral exposure to nickel through dental braces prior to ear piercing reduces the risk of developing nickel allergy. ${ }^{6,40}$

Oral administration of nickel sulfate $5.0 \mathrm{mg}$ once a week for 6 weeks in nickel-allergic patients significantly reduced the degree of contact allergy, as measured by patch test reactions before and after nickel administration. ${ }^{17}$

Oral hyposensitization with increasing ( $0.3 \mathrm{ng}$ to $3000 \mathrm{ng} /$ week) doses of oral nickel sulfate associated 
with an elimination diet was able to induce partial or total remission of symptoms in 24 patients after 16 months with 20 patients remaining symptom-free after reintroduction of a nickel-containing diet. ${ }^{118}$ Although "nickel vaccination" using oral hyposensitizing treatment is commercially available in some countries its efficacy is still to be definitively proven. ${ }^{119}$

\section{Alitretinoin (9-cis retinoic acid)}

This oral retinoid has been described as a promising new option in treatment of chronic, severe, and refractory hand dermatitis. This substance is a pan-agonist that binds to retinoic acid receptors $A$ (RAR) and X (RXR), acting as anti-inflammatory and immunomodulator. ${ }^{120-122}$

\section{Occupational allergy}

Evaluation of patients with possible occupational nickel allergy requires a detailed history that includes possible sources of exposure, daily activities, past and current occupations, manipulation of products, environmental conditions, use of personal protection equipment, and identification of other workers similarly affected in the same workplace. However, occupational ACD usually but not always improves on weekends and during holidays.

Nickel occupational ACD presents most commonly as hand eczema, as hands are constantly exposed to work tools that release nickel. The condition can lead to inability to work, as the hands are necessary in the majority of work tasks.

It has been shown by several studies that nickel exposure can be quantified by nickel content in nails and skin. Such measurements provide an objective evaluation of occupational exposure in nickel-sensitized individuals with hand dermatitis, but are not available in daily practice. ${ }^{123}$ After diagnosing an occupational ACD related to nickel, some recommendations are needed.

Depending on sensitization degree and clinical presentation it might be necessary to temporarily remove the worker from his tasks. Sometimes it might be necessary to rehabilitate the worker in another function where there is no contact with nickel.

Besides the preventive and therapeutical strategies generally recommended for nickel-sensitized individuals, already discussed in this article, there is the necessity to improve the workplace environment by eliminating and substituting metallic tools.

Good occupational hygiene is mandatory, especially for workers in contact with platters and batteries, which release a considerable amount of nickel salts that can contaminate gloves and clothing.
Use of personal protective equipment, particularly gloves made of polyvinyl chloride (PVC), is important. ${ }^{124}$

\section{Prognosis}

Once an individual has become sensitized to nickel, it will be a life-long condition. Early diagnosis and proper management are fundamental. If the individual can prevent contact with items that release this metal, the prognosis is often good.

Factors associated with a bad prognosis include continuous nickel exposure, involvement of the hands, secondary bacterial infection, history of atopy, and multiple contact allergies.

\section{Conclusion}

Nickel is the most common sensitizing agent worldwide. Allergic contact dermatitis due to this metal represents great morbidity, as well as cases of systemic allergic contact dermatitis, which can be misdiagnosed as adverse drug reactions, delaying the correct diagnosis and leading to inappropriate treatment. Studies in work adaptability and quality of life are needed, as no data have been published in this field.

\section{Disclosures}

None of the authors declare conflicts of interest.

\section{References}

1. The International Nickel Company. Romance of nickel. New York; 1960.

2. Liden C. Nickel in jewelry and associated products. Contact Dermatitis. 1992;26:73-75.

3. Thyssen JP, Linneberg A, Menne T, Johansen JD. The epidemiology of contact allergy in the general population - prevalence and main findings. Contact Dermatitis. 2007;57:287-299.

4. Nielsen NH, Menne T. Allergic contact sensitization in an unselected Danish population. The Glostrup Allergy Study, Denmark. 1992 Acta Derm Venereol Suppl (Stockh). 1992;72:456-460.

5. Andersen KE, White IR, Goossens A. Allergens from the standard series. In: Frosch PJ, Menné T, Lepoittevin JP, editors. Contact dermatitis, 4th ed. New York. Springer; 2006. p. 455.

6. Mortz CG, Lauritsen JM, Bindslev-Jensen C, Andeersen KE. Nickel sensitization in adolescents and association with ear piercing, use of dental braces and hand eczema. Acta Derm Venereol Suppl (Stockh). 2002;82:359-364.

7. Schnuch A, Geier J, Uter W, et al. National rates and regional differences in sensitization to allergens of the standard series. Populationadjusted frequencies of sensitization (PAFS) in 40,000 patients from a multicenter study (IVDK). Contact Dermatitis. 1997;37(5):200-209.

8. Rees JL, Friedmann; Matthews JNS. Sex differences in susceptibility to dinitrochlorobenzene (DNCB). Br J Dermatol. 1989;129:371-371.

9. Shah M, Lewis FM, Gawkroder DJ. Nickel as an occupational allergen. Arch Dermatol. 1998;134:1231-1236.

10. Salim AA, Grotti A, Riscala CM. Nickel actions in the human body. An Bras Dermatol. 1987;62(2):85-96.

11. Walton S, Nayagam AT, Keczkes K. Age and sex prevalence of allergic contact dermatitis. Contact Dermatitis. 1986;15:136-139.

12. Walker FB, Smith PD, Maibach HI. Genetic factors in human allergic contact dermatitis. Int Arch Allergy. 1967;32:453-462. 
13. Hawes GE, Struyk L, van den Elsen PJ. Differential usage of T-cell receptor $\mathrm{V}$ gene segments in CD4+ and CD8+ subsets of T lymphocytes in monozygotic twins. J Immunol. 1993;150:2033-2045.

14. Thestrup-Pedersen K. Contact allergy in homozygous twins. Contact Dermatitis. 1997;36:52-53.

15. Thyssen JP, Carlsen BC, Menné T. Nickel sensitization, hand eczema, and loss-of-function mutations in the filaggrin gene. Dermatitis. 2008;19(6):303-307.

16. Marks JG, Belsito DV, DeLeo VA, et al. North American contact dermatitis group patch-test results, 1998-2000. Am J Contact Dermat. 2003;14:59-62.

17. The ESSCA Writing Group. The European Surveillance System of Contact Allergies (ESSCA): results of patch testing the standard series, 2004. J Eur Acad Dermatol Venereol. 2008;22:174-181.

18. Duarte I, Lazzarini R, Kobata CM. Contact dermatitis in adolescents. Am J Contact Dermat. 2003;14(4):200-202.

19. Larsson-Stymne B, Widstrom L. Ear piercing: a cause of nickel allergy in schoolgirls? Contact Dermatitis. 1985;13:289-293.

20. Meijer C, Bredberg M, Fischer T, Widstrom L. Ear piercing and nickel and cobalt sensitization in 520 young Swedish men doing compulsory military service. Contact Dermatitis. 1995;32:147-149.

21. Liden C. Nickel. In: Kanerva L, Elsner P, Wahlberg JE, Maibach HI: Handbook of occupational dermatology. New York: Springer; 2000.

22. Morgan LG, Flint GN. Nickel alloys and coatings: release of nickel. In: Maibach HI, Menné T, editors. Nickel and the skin: immunology and toxicology. CRC, Boca Raton; 1989. p. 45-54.

23. Hemingway JD, Molokhia MM. The dissolution of metallic nickel in artificial sweat. Contact Dermatitis. 1987;16:99-105.

24. Menne T, Rasmussen K. Regulation of nickel exposure in Denmark. Contact Dermatitis. 1990;23:57-58.

25. European Communities. European Dir. 94/27/EC of 30 June 1994 amending for the 12 th time Dir. 76/769/EEC on the approximation of the laws, regulations and administrative provisions of the Member States relating to restrictions on the marketing and use of dangerous substances. Official J Eur Communities. 1994;37:1-2.

26. Jensen CS, Lisby S, Baadsgaard O, Volund A, Menné T. Decrease in nickel sensitization in a Danish schoolgirl population with ears pierced after implementation of the nickel-exposure regulation. Br J Dermatol. 2002;146:636-642.

27. Schnuch A, Geier J, Lessmann H, Uter W. Decrease in nickel sensitization in young patients - successful intervention through nickel exposure regulation? Results of IVDK, 1992-2001 Hautarzt. 2003;54(7): 626-632.

28. Gawkrodger DJ. Nickel dermatitis: how much nickel is safe? Contact Dermatitis. 1996;35:267-271.

29. Rasenen L, lehto M, Mustikka-Maki U. Sensitization to nickel from stainless steel ear piercing kits. Contact Dermatitis. 1993;28:292-293.

30. Basketter DA, Briatico-Vangosa G, Kaestner W, Lally C, Bontinck WJ. Nickel, cobalt and chromium in consumer products: a role in allergic contact dermatitis? Contact Dermatitis. 2003;28:15-25.

31. Basketter DA, Angelini G, Ingber A, Kern PS, Menné T. Nickel, cobalt and chromium in consumer products: a role in allergic contact dermatitis? Contact Dermatitis. 2003;49:1-7.

32. Fisher AA. Patch testing in children including early infancy. Cutis. 1994;54:387-388.

33. Seidenari S, Manzini BM, Motolese A. Contact sensitization in infants: report of 3 cases. Contact Dermatitis. 1992;27:319-320.

34. Mallory SB. The pediatric patient. In: Guin JD, editor. Practical contact dermatitis. McGraw-Hill, New York; 1995. p. 603-616.

35. Silverberg NB, Licht J, Friedler S, Sethi S, Laude TA. Nickel contact hypersensitivity in children. Pediatr Dermatol. 2002;19: 110-113.

36. Fisher AA. Nickel dermatitis in children. Cutis. 1991;47:19-21.

37. Fisher AA. Allergic contact dermatitis in early infancy. Cutis. 1994;54:300-302.

38. Kerosuo H, Kanerva L. Systemic contact dermatitis caused by nickel in a stainless steel orthodontic appliance. Contact Dermatitis. 1997;36:112-113.
39. Veien NK, Borckhorst E, Hattel T, Laurberg G. Stomatitis nor systemically-induced contact dermatitis from metal wire in orthodontic materials. Contact Dermatitis. 1994;30:210-213.

40. Van Hoogstraten IMW, Andersen KE, von Blomberg BME, et al. Reduced prevalence of nickel allergy upon oral nickel contact at an early age. Clin Exp Immunol. 1991;85:441-445.

41. Antony FC, Holden CA. Metal allergy resurfaces in failed hip endoprostheses. Contact Dermatitis. 2003;48:49-50.

42. Duarte I, Amorim JR, Perázzio EF, Schmitz Junior R. Metal contact dermatitis: prevalence to nickel, cobalt and chromium. An Bras Dermatol. 2005;80(2):137-142.

43. Warshaw EM, Belsito DV, DeLeo VA, et al. North American Contact Dermatitis Group patch-test results, 2003-2004 study period. Dermatitis. 2008;19(3):129-136.

44. Liden C. Nickel. In: Kanerva L, Elsner P, Wahlberg JE, Maibach HI, editors. Handbook of occupational dermatology. New York: Springer; 2000. p. 525.

45. Wall LM Nickel penetration through rubber gloves. Contact Dermatitis. 1980;6:461-463.

46. Meding B. Differences between the sexes with regard to work-related skin disease. Contact Dermatitis. 2000;43(2):65-71.

47. Vandenberg JJ, Epstein WL. Experimental nickel contact sensitization in men. J Invest Dermatol. 1963;41:413-418.

48. Kligman AM. Identification of contact allergens by human assay, II. Factors influencing the induction and measurement of allergic contact dermatitis. J Invest Dermatol. 1996;47:375-392.

49. Wahlberg JE, Boman AS. Cross-reactivity to palladium and nickel studied in the guinea pig. Acta Derm Venereol Suppl (Stockh). 1992;72:95-97.

50. Liden C, Wahlberg JE. Cross-reactivity to metal compounds studiel in guinea pigs induced with chromate or cobalt. Acta Dermatol Venereol Suppl (Stockh). 1994;74:341-343.

51. Lidén C, Wahlberg JE, Maibach HI. Skin. In: Goyer RA, Klassen CD, Waalkes MP, editors. Metal toxicology. San Diego:Academic Press; 1995. p. 447-463.

52. Lammintausta K, Pitkänen OP, Kalimo K, Jansen CT. Interrelationship of nickel and cobalt contact sensitization. Contact Dermatitis. 1985;13(3):148-152.

53. Lammintausta $\mathrm{K}$, Kalimo $\mathrm{K}$. Do positive nickel reactions increase nonspecific patch test reactivity? Contact Dermatitis. 1987;16: 160-163.

54. Byer TT, Morrell DS. Periumbilical allergic contact dermatitis: blue jeans or belt buckles? Pediatr Dermatol. 2004;21:223-226.

55. Massimiliano P, Pasquale L, Colombina V, Antonella T. Contact dermatitis from nickel in mobile phones. Contact Dermatitis. 2000;42:362-363

56. Ehrlich A, Kucenic M, Belsito DV. Role of body piercing in the induction of metal allergies. Contact Dermatitis. 2001;12: 151-155.

57. Starace M, Militello G, Pazzaglia M, Vicenzi C, Tosti A. Allergic contact dermatitis to nickel in a hair clasp. Contact Dermatitis. 2007;56(5):290

58. Andersen KE, Hjorth N, Menné T. The baboon syndrome: systemically induced allergic contact dermatitis. Contact Dermatitis. 1984;10:97-101.

59. Menné T, Holm NV. Hand eczema in nickel-sensitive female twins. Genetic predisposition and environmental factors. Contact Dermatitis. 1983;9:289-296.

60. Menné T, Borgan O, Green A. Nickel allergy and hand dermatitis in a stratified sample of the Danish female population: an epidemiological study includinga statistic appendix. Acta Derm Venereol Suppl (Stockh). $1982 ; 62: 35-41$

61. Bryld LE, Hindsberg C, Kyvik KO, Agner T, Menné T. Risk factors influencing the development of hand eczema in a population-based twin sample. Br J Dermatol. 2003;149:1214-1220.

62. Kolodziej T, Szepietowski JC, Sikora J, Bialynicki-Birula R. The baboon syndrome due to nickel. Acta Dermatovenerol Croat. 2003;11:29-31. 
63. Jensen CS, Lisby S, Larsen JK, Veien NK, Menné T. Characterization of lymphocyte subpopulations and cytokine profiles in peripheral blood of nickel-sensitive individuals with systemic contact dermatitis after oral nickel exposure. Contact Dermatitis. 2004;50(1):31-38.

64. Osmundesen PE. Contact urticaria from nickel and plastic additives (butylhydroxytoluene, oleylamide). Contact Dermatitis. 1980;6:452.

65. Lombardi F, Campolmi P, Sertoli A. Lichenoid dermatitis caused by nickel salts? Contact Dermatitis. 1983;9:520-521.

66. Meneghine CL, Lichenoid contact dermatitis. Contact Dermatitis. 1971; Newslett 9:194.

67. Rietschel RL, Conde-Salazar R, Gooseens A, Veien NK. Patterns of contact dermatitis. In: Rietschel RL, Conde-Salazar R, Gooseens A, Veien NK, editors. Atlas of contact dermatitis 1st ed. New York: Martin Dunitz Ltd; 1999. p. 123.

68. Clemmensen OJ, Menné T, Kaaber K, Solgaard P. Exposure of nickel and the relevance of nickel sensitivity among hospital cleaners. Contact Dermatitis. 1981;7:14-18.

69. Cronin E. Clinical prediction of patch test results. Trans St Johns Hosp Dermatol Soc. 1972;58:153-162.

70. Balato A, Balato N, Di Costanzo L, Ayala F. Contact sensitization of older patients in an academic department in Naples, Italy. Dermatitis. 2008;19(4):209-212.

71. Brasch J, Geier J. Patch test results in schoolchildren. Contact Dermatitis. 1997;37:286-293.

72. Memon AA, Friedmann PS. Studies on reproducibility of allergic contact dermatitis. Br J Dermatol. 1996;134:208-214.

73. Andersen KE, Liden C, Hansen J, Volund A. Dose-response testing with nickel sulfate using the TRUE test in nickel-sensitive individuals Multiple nickel sulfate patch-test reactions do no cause an 'angry back.' Br J Dermatol. 1993;129:50-56.

74. Hindsen M, Bruze M, Christensen OB. Individual variation in nickel patch test reactivity. Am J Contact Dermat. 1999;10:62-67.

75. Wahlberg JE, Goossens A. Use to patch tes concentrations for adults in children and their influence on test reactivity. Occup Environ Dermatol. 2001;49:97-101.

76. Fisher AA. The dimethylglyoxime test in the prevention and management of nickel dermatitis. Cutis. 1990;46:467.

77. Rietschel RL, Fowler JF. Contact dermatitis and other reactions to metals. In: Rietschel RL, Fowler JF, editors. Fisher's contact dermatitis 4th ed. New York: Williams and Wilkins; 1996. p. 857.

78. Jensen CS, Menné T, Lisby S, Kristiansen J, Veien NK. Experimental systemic contact dermatitis from nickel: a dose-response study. Contact Dermatitis. 2003;49:124-132.

79. Veien N. Systemically induced eczema in adults. Acta Derm Venereol Suppl (Stockh). 1989;147:1-58.

80. Burrows D. The Prosser White oration 1988. Mischievous metals - chromate, cobalt, nickel and mercury. Clin Exp Dermatol. 1989;14(4):266-272.

81. Santucci B, Manna F, Cristaudo A, Cannistraci C, Capparella MR, Picardo M. Serum concentrations in nickel-sensitive patients after prolonged oral administration. Contact Dermatitis. 1990;22:253-256.

82. Nielsen GD, Jepsen LV, Jorgensen PJ, Grandjean P, Brandrup F. Nickelsensitive patients with vesicular hand eczema: oral challenge with a diet naturally high in nickel. Br J Dermatol. 1990;122:299-308.

83. Christensen OB, Möller H. External and internal exposure to the antigen in the hand eczema of nickel allergy. Contact Dermatitis. 1975;1: 136-141.

84. Kaaber K, Veien NK, Tjell JC. Low nickel diet in the treatment of patients with chronic nickel dermatitis. Br J Dermatol. 1978;98:197-201.

85. Kaaber K, Menné T, Tjell JC, Veien N. Antabuse treatment of nickel dermatitis. Chelation - a new principle in the treatment of nickel dermatitis. Contact Dermatitis. 1979;5:221-228.

86. Veien NK, Hattel T, Justesen O, Norholm A. Oral challenge with nickel and cobalt in patients with positive patch tests to nickel and/or cobalt. Acta Derm Venereol Suppl (Stockh). 1987;67:321-325.

87. Menné T, Veien NK, Sjølin K-E, Maibach HI. Systemic contact dermatitis. Am J Cont Dermat. 1994;5:1-12.
88. Hindsén M. Clinical and experimental studies in nickel allergy. Acta Derm Venereol Suppl (Stockl). 1999;204:1-22.

89. Hindsen M, Bruze M, Christensen OB. Flare-up reactions after oral challenge with nickel in relation to challenge dose and intensity and time of previous patch test reactions. J Am Acad Dermatol. 2001;44:616-623.

90. Allenby CF, Basketter DA. The effect of repeated open exposure to low levels of nickel on compromised hand skin of nickel-allergic patients. Contact Dermatitis. 1994;30:135-138.

91. Sanchez APG, Maruta CW, Sato MN, Ribeiro RL, Zomignan CA, Nunes RS, Reis VMS. Study on lymphocyte proliferation in nickel sensitive patients. An Bras Dermatol. 2005;80(2):149-158.

92. Möller H. Intradermal testing in doubtful cases of contact allergy to metals. Contact Dermatitis. 1989;20(2):120-123.

93. Meneghini C, Angelini G. Intradermal test in contact allergy to metals Acta Derm Venereol Suppl (Stockh). 1979;59(85):123-124.

94. Kalimo K, Lammintausta K, Jalava J, Niskanen T. Is it possible to improve the prognosis in nickel contact dermatitis? Contact Dermatitis. 1997;37:121-124.

95. Sprigle AM, Marks JG Jr, Anderson BE. Prevention of nickel release with barrier coatings. Dermatitis. 2008;19(1):28-31.

96. Diepgen TL, Weisshaar E Contact dermatitis: epidemiology and frequent sensitizers to cosmetics. J Eur Acad Dermatol Venereol. 2007;21 Suppl 2:9-13.

97. Le Coz C-J, Leclere J-M, Arnoult E, Raison-Peyron N, Pons-Guiraud A, Vigan M. Allergic contact dermatitis from shellac in mascara and eye shadows. Contact Dermatitis. 2002;46:149-152.

98. Sainio AL, Jolanki R, Hakala E, Kanerva L. Metals and arsenic in eye shadows. Contact Dermatitis. 2000;42:5-10.

99. Mastromattteo E. Nickel and its compounds. In: Zenz C, Dickerson OB, Horvath EP Jr, Editors. Occupational medicine 3rd ed. St Louis: Mosby; 1994. p. 563.

100. Hogan DJ, May J. Allergic Contact Dermatitis. In Emedicine. Updated Mar 7, 2007. Available from http//www.emedicine.medscape.com.

101. Bhardwaj SS, Jaimes JP, Liu A, Warshaw EM. A double-blind randomized placebo-controlled pilot study comparing topical immunomodulating agents and corticosteroids for treatment of experimentally induced nickel contact dermatitis. Dermatitis. 2007;18(1):26-31.

102. Saripalli YV, Gadzia JE, Belsito DV. Tacrolimus ointment $0.1 \%$ in the treatment of nickel-induced allergic contact dermatitis. J Am Acad Dermatol. 2003 Sep;49(3):477-482.

103. Kalimo K, Lammintausta K, Viander M, Jansén CT.PUVA treatment of nickel contact dermatitis: effect on dermatitis, patch test sensitivity, and lymphocyte transformation reactivity. Photodermatol. 1989;6(1):16-19.

104. Gawkrodger DJ, Healy J, Howe AM. The prevention of nickel contact dermatitis. A review of the use of binding agents and barrier creams. Contact Dermatitis. 1995;2:257-265.

105. Kurtin A, Orenteich N, Kurtin A. Chelation deactivation of nickel in allergic eczematous sensitivity. J Invest Dermatol. 1954;22:441-445.

106. Fullerton A, Menné T. In vitro and in vivo evaluation of barrier gels in nickel contact allergy. Contact Dermatitis. 1995;32:39-45.

107. Memon AA, Molokhia MM, Friedman PS. The inhibitory effects of topical chelating agents and antioxidants on nickel-induced hypersensitivity reactions. J Am Acad Dermatol. 1994;30:560-565.

108. Wöhrl S, Kriechbaumer N, Hemmer W, Focke M, Brannath W, Götz M, Jarisch R. A cream containing the chelator DTPA (diethylenetriaminepenta-acetic acid) can prevent contact allergic reactions to metals. Contact Dermatitis. 2001;44(4):224-228.

109. Menné T, Kaaber K. Treatment of pompholyx due to nickel allergy with chelating agents. Contact Dermatitis. 1978;4:289-290.

110. Kolpakov FI. The role of protective external preparations in the prevention of the penetration of chromium and nickel into the skin. Vestn Derm I Vener. 1964;38:8-12.

111. Hogan DJ, Dannaker CJ, Lal S, Maibach HI. An international survey on the prognosis of occupational contact dermatitis of the hands. Derm Beruf Umwelt, 1990;35:143-147. 
112. Starek A. Barrier creams in the prevention of occupational contact dermatitis - an experimental study. Pol J Occup Med Environ Health. 1991:4;261-268.

113. Veien NK, Menné T. Nickel contact allergy and a nickel-restricted diet. Semin Dermatol. 1990;9:197-205.

114. Veien NK, Hattel T, Justesen O, Norholm A. Dietary treatment of nickel dermatitis. Acta Derm Venereol Suppl (Stockh). 1985;65:138-142.

115. Antico A, Soana R. Chronic allergic-like dermatopathies in nickelsensitive patients. Results of dietary restrictions and challenge with nickel salts. Allergy Asthma Proc. 1999;20:235-242.

116. Veien NK, Hattel T, Laurberg G. Low nickel diet: an open, prospective trial. J Am Acad Dermatol. 1993;29:1002-1007.

117. Sjovall P, Christensen OB, Moller H. Oral Hyposensitization in nickel allergy. J Am Acad Dermatol. 1987;17:774-778.

118. Minelli M, Schiavino D, Musca F, Bruno ME, Falagiani P, Mistrello G, et al. Oral hyposensitization to nickel in patients with systemic nickel allergy syndrome. Int J Immunopathol Pharmacol. 2008. In press.
119. Minelli M. Nickel vaccination: today and tomorrow. Int J Immunopathol Pharmacol. 2005;18(4 Suppl):19-20.

120. Molin S, Ruzicka T. Alitretinoin: a new treatment option for chronic refractory hand eczema. Hautarzt. 2008;59(9):703-704, 706-709.

121. Raap U, Kenneweg C, Kapp A, Werfel T. New and rarely used treatment options for refractory hand eczema: local UVA-1 phototherapy, retinoids, calcineurin inhibitors. Hautarzt. 2008;59(9):710-716.

122. Wollina U. Pompholyx: what's new? Expert Opin Investig Drugs. 2008;17(6):897-904.

123. Liden C, Bruze M, Menné T. Metals. In: Frosch PJ, Menné T, Lepoittevin JP, editors. Contact dermatitis 4th ed. New York; Springer; 2006. p. 541 .

124. Rietschel RL, Fowler JF. Contact dermatitis and other reactions to metals. In: Rietschel RL, Fowler JF, editors. Fisher's contact dermatitis 4th ed. New York: Williams and Wilkins; 1996. p. 847. 